\title{
Are Backbenchers Fighting Back? : Intra-Party Contestation in German Parliament Debates on the Greek Crisis
}

\section{Bhattacharya, Caroline}

2019-04

Bhattacharya , C \& Papageorgiou , A 2019 , ' Are Backbenchers Fighting Back? Intra-Party Contestation in German Parliament Debates on the Greek Crisis ' , Parliamentary Affairs, vol. 72 , no. 2 , pp. 425-444 . https://doi.org/10.1093/pa/gsx077

http://hdl.handle.net/10138/301333

https://doi.org/10.1093/pa/gsx077

acceptedVersion

Downloaded from Helda, University of Helsinki institutional repository.

This is an electronic reprint of the original article.

This reprint may differ from the original in pagination and typographic detail.

Please cite the original version. 
Title:

Are Backbenchers Fighting Back? Intra-Party Contestation in German Parliament Debates on the Greek Crisis

Running head: Are Backbenchers Fighting Back?

\section{Article Category:}

Original article part of special section '(Dis)Unity in Parliamentary Parties: Determinants and Processes'

Authors:

Caroline Bhattacharya

Achillefs Papageorgiou

\section{Affiliation:}

Department of Political and Economic Studies, University of Helsinki, Finland

\section{Corresponding author:}

C. Bhattacharya

Department of Political and Economic Studies, University of Helsinki Unioninkatu 37 (P.O. Box 54), 00014 University of Helsinki, Finland caroline.bhattacharya@helsinki.fi

\section{Supplementary data}

Appendices are available at Parliamentary Affairs online.

\section{Acknowledgements:}

This article is supported by the Finnish Cultural Foundation in the form of a doctoral research grant received by Caroline Bhattacharya.

We are grateful to Dr. Caroline Close and Dr. Sergiu Gherghina for their detailed comments. We also thank the participants at the 2017 ECPR Joint Sessions Workshop 'Rethinking Intraparty Cohesion in Times of Party Transformation' and our department colleagues Dr. Hanna Wass, Dr. Tero Erkkilä, Prof. Anne Holli and Prof. Mikko Mattila for their feedback. 


\section{ARE BACKBENCHERS FIGHTING BACK? INTRA-PARTY CONTESTATION IN GERMAN PARLIAMENT DEBATES ON THE GREEK CRISIS}

Over the course of the Eurozone crisis, we have witnessed a disintegration of the pro-European consensus in the German Bundestag. This study focuses on patterns of intra-party contestation by examining individual-level determinants of the growing party disunity. Party leaders constrain the room of manoeuvre of individual legislators, but the degree of party control they face varies depending on their position within the party, and we expect this to be reflected in their behaviour. Our comprehensive case study of plenary debates on the Greek crisis in the Bundestag (2010-2015) analyses legislative speech, voting defection and explanations of vote. Our results show that an MP's rank, experience, electoral mandate and gender matter in their inclination to voice dissent. Here, the frontbencher-backbencher categorisation shows the most consistent effect.

Keywords: euro crisis; Germany; legislative behaviour; party unity; politicisation

Studies on the Europeanisation of national parliaments and the domestic politicisation of European Union (EU) issues tend to focus on member-state legislatures as collective actors, failing to draw on the key insights from the literature on legislative parties, which are not unitary actors either. This article attempts to make this link by combining a party perspective with an individual-level approach in order to enhance our understanding of the actors and inner workings that drive or impede the parliamentarisation of EU politics. According to Raunio and Hix (2000, p. 163), the processes whereby national parliaments claim back control from executive actors by redressing the information asymmetry and introducing 
scrutiny instruments is driven by 'the desire by non-governing parties and backbench parliamentarians'. In this article, we test whether backbenchers have indeed learned to fight back. More precisely, we empirically investigate the recent disintegration of the proEuropean consensus in the German lower house, the Bundestag, and we ask to what extent this can be explained by dissent within rather than between parties by looking at both partylevel and individual-level determinants.

The Eurozone crisis provides an exemplary case for testing whether it is no longer merely executive actors and a small number of frontbenchers and 'Euro-wizards' who take charge of EU debates. The crisis has shifted EU decision-making to the forefront of public debate and protest. This is even the case in Germany, where traditionally public support for European integration has been strong and where the Bundestag has been characterised by a solid pro-EU cross-partisan consensus. Germany can be regarded as a 'high barrier system' where challenger parties do not emerge easily (Hooghe and Marks, 2017); and after the Eurosceptic Alternative for Germany narrowly missed entering the Bundestag in 2013, contestation intensified and cracks widened particularly among the Christian Democrats. Narrowing down on the Greek debt crisis allows us to examine patterns of intra-party contestation for one specific issue that has become increasingly controversial between 2010 and 2015 .

Our analysis of roll-call votes (RCVs) suggests that voting unity only tells us part of the story because some parties enforce discipline more strictly than others and the incentive to toe the party line varies between different categories of members of parliament (MPs). Therefore, we also examine which MPs give plenary speeches and deliver explanations of vote (EoVs). In the Bundestag party leaders tightly control access to the plenary floor, which means that plenary debates may project disproportionate party cohesion, as backbenchers and dissenting MPs are unlikely to receive speaking time. But any MP can deliver an EoV to 
provide justification for her voting decision and/or voice reservations. These written statements are signed by one or more MPs, annexed to the official minutes and often published on MPs' personal websites. EoVs are therefore a very useful additional data source for the study of party cohesion.

Our comprehensive approach addresses some of the limitations faced by studies that focus solely on voting behaviour, primarily because we shift the focus from preferences to the incentive and opportunity structures of legislators and look at individual-level behaviour in the context of institutional constraints. Our analysis confirms the significance of party control in setting the room of manoeuvre for individual MPs and thereby determining levels of observed party unity. We test how an MP's electoral mandate, length of membership and rank affect her legislative behaviour in terms of raising dissent. While we find some evidence that mandate, experience as well as gender matter, the distinction between frontbenchers and backbenchers shows the most consistent effect. Another key finding is that EoVs provide a meaningful channel of expression for MPs with limited influence. The act of giving an EoV may not be considered a serious challenge to party unity due to its limited public visibility, but we observe a sequential relationship between EoVs and future voting defection.

\section{EU politicisation in national parliaments and party (dis)unity: The case of the German Bundestag}

The literature on the role of national parliaments in the EU has shifted from measuring and ranking their legislative scrutiny and oversight capabilities, i.e. government-related function, to their communicative activities, i.e. citizen-related function, and correspondingly the concept of politicisation has increasingly featured in these studies (e.g. Miklin, 2014; Rauh, 2015; Wendler, 2016) to enhance our understanding of the conditions, mechanisms and 
actors that drive parliamentary contention of EU issues. In line with de Wilde's (2011, pp. 566-567) conceptualisation of politicisation as 'an increase in polarization of opinions, interests or values and the extent to which they are publicly advanced towards policy formulation within the EU', we also emphasise controversiality and public visibility when defining politicisation as the making visible of conflicting alternatives. The contentious nature of EU issues needs to not only be detected by parliamentary actors but also communicated to the public. For national parliaments to communicate divergent views on EU matters, it seems crucial that a diverse range of parliamentary actors is involved. Thus, this study shifts the focus from the collective level to the level of legislative parties and individual legislators.

Empirical research has shown that mainstream political parties are more pro-European than their voters (Mattila and Raunio, 2012) and collectively offer voters little choice with respect to EU integration (van der Eijk and Franklin, 2004). Internally, however, they more divided over EU politics than over economic left/right and social libertarian/authoritarian issues (Edwards, 2009; Hooghe and Marks, 2017). Cleavage theory suggests that conservative parties with a centrist position on European integration are particularly susceptible to internal dissent because they support economic integration while simultaneously defending national sovereignty against further political integration and the nation state against the socio-cultural effects of transnationalism (Marks and Wilson, 2000; Edwards, 2009). Assuming that party leaderships have a strong incentive - and means at disposal - to maintain a coherent party label, this begs the question to what extent and how the lack of party unity over EU politics manifests itself in legislative behaviour.

As Germany is the largest creditor country (contributing around $27 \%$ to the euro crisis measures), the Bundestag's budget sovereignty was at stake, and public opinion was highly sceptical about offering transnational solidarity in the form of financial assistance. The events 
around the euro crisis presented German MPs with an unprecedented stimulus to demand involvement and voice their views, even if these may contradict party line. The Bundestag is a comparatively strong chamber in terms of its institutional powers but should be considered an unlikely case for politicisation. It is typically described as a 'working parliament' with a strong focus on legislative scrutiny in the standing committees rather than heated debates in the plenum. Despite strong opposition rights and a moderately strong EU scrutiny system, contestation of EU affairs is generally limited due to a solid pro-European consensus among the major parties (Auel and Raunio, 2014). As Kröger and Bellamy (2016, p. 145) note, 'EU issues have been most debated in [national parliaments] where consensus is greatest rather than where it is weakest [and] Germany in particular fits this pattern'.

\section{Theorising party (dis)unity and legislative behaviour}

When shifting the focus to MPs' incentives and opportunities to voice discontent with the party line on EU issues, we need to gain a comprehensive understanding of the type of legislators who are willing and in a position to invest resources and express their opinion in EU debates, while taking into account the role of legislative parties in constraining their room of manoeuvre. Legislative parties are internally divided, deeply hierarchical organisations, in which the leadership feels the responsibility to maintain unity and possesses a significant amount of resources, disciplinary instruments and rewards to do so (Bailer, 2017). Conceptually, we can make a distinction between party cohesion and party discipline, that is, between substantive agreement based on shared preferences, on the one hand, and cooperation under compulsion and anticipated sanctions, on the other hand (Hazan, 2014). Empirically, however, we face an observability problem, since the 'black box' of legislative parties makes it challenging to determine the impact of party control on legislative behaviour. 


\section{[Insert Figure 1 here]}

Following Proksch and Slapin's (2015a) theory, the level of latent intra-party disagreement determines which action MPs choose, i.e. the observable party disunity: While 'defecting from one's party leadership on a vote, especially on one that is both high profile and whipped, constitutes the ultimate act of defiance' (ibid., p. 26), voting defection is not the only way parties display disunity. In theory, EoVs and speeches offer outlets for lesser disagreement. Once we take into account contextual factors, in particular established

practices of party control (see Figure 1), we would, however, expect plenary debates to show the lowest level of intra-party disunity. Plenary debates are highly visible to the public, more so than RCVs, and in the case of the Bundestag party leaders have formal control of the plenary floor by deciding who gets to speak on behalf of the parliamentary party group and for how long. Proksch and Slapin (2015b) find that in highly salient debates, German party leaders are more likely to speak themselves and MPs who are ideologically distant from the party leadership tend to give fewer speeches (whereas the opposite is the case in the House of Commons). Bailer (2017, p. 7) quotes a party group leader in the Bundestag: 'Of course, you are only allowed to talk in the morning when Phoenix [public TV news channel] is reporting if you are a loyal party group member. The dissenters are only allowed at night.' Since there are no party political constraints for the usage of EoVs, it provides a channel to explain defection or communicate reservations despite voting along party line (Sieberer, 2015). Although its public visibility is relatively low, the usage of EoVs is a good measure of contestation within parliamentary party groups.

\subsection{Individual-level determinants of disunity in the context of party control}

The variety of control mechanisms and disciplinary measures do not affect legislators 
equally. The threshold of communicating dissent is contingent upon the mandate, experience and rank of the individual MP, and personal characteristics such as gender could be relevant as well.

The Bundestag employs a mixed-member proportional system, and existing studies (Sieberer, 2010; Manow, 2013; Ohmura, 2014; Degner and Leuffen, 2016) provide mixed results regarding the question whether behavioural differences exist between MPs elected from single-member districts and MPs elected via closed party lists. Studies that do find more rebellious behaviour among district MPs emphasise the explanatory power of the competition and strategy for re-election. If district MPs seek the personal vote (Gschwend and Zittel, 2015), they are prone to engage in constituency service and 'feel the need to differentiate themselves from their parliamentary party by taking positions countering party stands or even by voting against their party on issues that are salient to constituents (especially when government survival is not at stake)' (André et al., 2014, pp. 87-88, emphasis added), and those issues are not necessarily local issues. The euro crisis has certainly become a prominent issue, and given that political parties are generally more pro-European than their voters (Mattila and Raunio, 2012), the question arises whether district MPs are more responsive to the electorate in EU affairs ${ }^{1}$.

H1: District MPs are more likely to vote against party line and express discontent in EoVs, but we do not expect mandate type to matter for speech.

In line with previous studies (e.g. Becher and Sieberer, 2008), we hypothesise that German legislators in executive, parliamentary or party office are less likely than backbenchers to

\footnotetext{
${ }^{1}$ The German Politikbarometer survey from September 2011 revealed that when asked which party best represents their interests in managing the euro crisis $14 \%$ of respondents said none and $28 \%$ were not able to answer the question (http://www.forschungsgruppe.de/Umfragen/Politbarometer/Archiv/Politbarometer_2011/ Oktober_II/, accessed 4 March 2017).
} 
defect from party line or publicly disagree with the position of their party. Hence, they should be allowed to speak more often.

$\mathrm{H} 2$ : Voting defection is likely to be driven by backbenchers, while plenary debates tend to be dominated by frontbenchers.

From the literature on parliamentary socialisation we know that 'the ambition of newcomers to gain political influence and their lack of resources necessary to achieve this goal are the central incentives for these junior legislators to adapt to the internal rules and norms' (Best and Vogel, 2014, p. 60). Thus, our expectation is that lack of experience, measured in years of membership in parliament, is correlated with conformist behaviour.

H3a: Experienced MPs are more likely to express dissent in terms of voting behaviour, and EoVs could be a useful channel of communication for less experienced MPs who lack access to the plenary floor.

Kam (2014, p. 404) suggests that 'the most rebellious MPs are those who have been demoted from the front-bench (and who are unlikely therefore to be ministers again), or those who failed to secure a promotion early in their parliamentary careers (and who are likely therefore to languish on the backbenches throughout their careers)'. We therefore also test for a combined effect of experience and rank.

H3b: Longer-serving MPs with a backbench position are more inclined to defect and less likely to speak.

While the existing literature provides very little evidence of a gender effect with regards to party unity (see Cowley and Childs, 2003 for an exception), Bäck et al. (2014) find that gender could play a role in the allocation of floor time. Female underrepresentation is particularly pronounced in debates on 'harder' policy issues such as macroeconomics, transportation, finance and energy. Although the reasons for female underrepresentation in 
specific policy areas are still subject to debate, we expect some gender-based division of labour in debates on the euro crisis, which despite its complexity can be considered predominantly a macroeconomic and fiscal issue.

H4: Women MPs are less likely to give plenary speeches and EoVs and are possibly less inclined to defect.

\section{Data, variables and methods}

Between May 2010 and August 2015, the Bundestag passed 12 acts (see Table 1) on the euro crisis, out of which five concerned aid packages for Greece. The Greek crisis has been debated for more than ten hours in the plenary assembly, amounting to 74 speeches and 15 interventions/questions. In total, MPs issued 410 EoVs regarding the euro crisis, out of which 240 EoVs were in relation to RCVs on the Greek situation.

[Insert Table 1 here]

We collected data of all activities related to the votes on the Greek crisis. The period of observation stretches across two legislative periods ${ }^{2}$, and our data set comprises of $881 \mathrm{MPs}$, out of which 394 of have actively participated in the debates. In total, we have 1240 observations, that is, occasion where an individual legislator has delivered a plenary speech, cast a defecting vote or issued an EoV. All votes related to euro crisis measures were recorded, which in itself tells us something about their public visibility and the level of importance attached to them, since, historically, only around $5 \%$ of votes in the Bundestag have been recorded (Bergmann et al., 2016, p. 26). A RCV needs to be requested by one party group or a minimum of $5 \%$ of total MPs and are generally used to increase public

\footnotetext{
${ }^{2}$ As a result of the 2013 elections, the FDP dropped out of the Bundestag, and the SPD joined the CDU and CSU for a 'grand coalition' government under Angela Merkel.
} 
attention for one's own position, to reveal internal divisions within political opponents or as a strategic measure to close ranks and deter potential dissenters (ibid., p. 31). When measuring defection as a form of individual-level dissent, we also take into account abstentions, which in our case can be clearly distinguished from being absent. In fact, entire party groups occasionally choose to abstain. Hence, any vote that does not follow the party line is counted as deviant ${ }^{3}$.

First, we sort our data in a long format so that every observation corresponds to a different parliamentary action relevant to the Greek crisis. We specify three Generalized Linear Latent and Mixed Models (GLLAMMs) with adaptive quadrature ${ }^{4}$, one for each type of individual-level activity. 'To relax the assumption of conditional independence among the responses for the same [person]' (Rabe-Hesketh and Skrondal, 2012, p. 247), we include a two-level model with a random intercept for subjects - MPs of the $17^{\text {th }}$ and $18^{\text {th }}$ term.

Our core independent variables are mandate, rank, experience and gender. Overall, $48 \%$ of Bundestag MPs hold a district mandate, but there is a large variation across party groups $^{5}$. Rank is a combination of four variables: an MP is considered a frontbencher if she was either a member of the government (Chancellor, Minister, Parliamentary secretary, Federal commissioner) or a member of the central party leadership (Party chair, Deputy party chair, General secretary, Treasurer, Member of executive board) or held a high-ranking position in the parliament (President, Vice President, Standing committee chair) or in the

\footnotetext{
${ }^{3}$ The party line is defined as the position adopted by the leadership. In July 2015, when the Bundestag voted on the government's mandate for negotiating the third aid package, the Greens did not have a whipped party line and this was reflected in very low voting unity. In this case, we could not count any votes as deviant to avoid skewed results.

${ }^{4}$ For a more detailed description, see Supplementary Material and Table S1.

${ }^{5}$ See Supplementary Table S2.
} 
parliamentary group (Parliamentary group chair, Deputy parliamentary group chair, (First) parliamentary manager). Experience reflects the years served in Bundestag until the year that each parliamentary action took place. We grouped MPs into four categories: eight years and less, nine to 16 years, 17 to 24 years, and 25 years and more. In order to test the combined effect of rank and experience, we add the dummy variable 'Backbencher_Experience $>8$ ', where backbenchers are MPs with no position of responsibility and experience means membership in the Bundestag for at least two terms (i.e. more than eight years). We also look for gender effects, and our analysis controls for party and government coalition.

\section{Empirical results}

Before testing our hypotheses to enhance our understanding of individual-level determinants of intra-party disunity, we present some descriptive findings to contextualise intra-party contestation of the Greek crisis.

\subsection{Descriptive findings}

In line with our theoretical expectation (see Figure 1 above), participation differs by the type of activity ${ }^{6}$. We observe that intra-party disunity in the form of defection has gradually increased, highlighting that disunity is a dynamic phenomenon contingent not only upon actors, but also issues and timing. Table 2 also shows that the highest activity levels are to be found for the usage of EoVs, and unsurprisingly the share of MPs giving a speech remained consistently low, since in the plenum time is a very scarce and controlled resource. A partial explanation for the higher levels of activity in 2015 is the fact that the Bundestag had to

\footnotetext{
${ }^{6}$ For variance between party groups, see Supplementary Table S3.
} 
return twice from summer recession only to debate and vote on the Greek crisis.

[Insert Table 2 here]

As illustrated in Figure 2, over the course of the crisis, all party groups have faced RCVs where their voting unity dropped well below average. When in 2015 the second aid package for Greece was extended and the third package was negotiated and passed, the disintegration of the consensus culminated in all parties with the exception of the Social Democrats (SPD), which became more united after joining the government in October 2013. We need to keep in mind that the government majority was much larger in the $18^{\text {th }}$ term, which means that government parties could 'afford' more deviant votes. In empirical reality, however, Bergmann et al.'s (2016, p. 47) longitudinal study does not provide convincing evidence of a majority size effect on voting unity after 1990.

[Insert Figure 2 here]

A growing number of EoVs were issued as well, indicating that German legislators felt a stronger need to communicate their views using the means available to them. We know from a recent study by Sieberer (2015, pp. 289-290) that 'the usage of EoVs ... constitutes nonstandard behaviour': in the $16^{\text {th }}$ term there were on average 3.1 EoVs by 12.4 individual signatories per RCV. Each single vote exceeded this average, and in February and July 2015 even every fifth MP gave an individual EoV or signed a joint one ${ }^{7}$. Our analysis of 240 written EoVs that 445 MPs delivered for the five voting sessions on the Greek crisis reveals that overall $45 \%$ of MPs use EoVs to express some doubts or differences of opinion despite voting with the party, another $22 \%$ explain defection and around one third support the party line in their statement ${ }^{8}$. Governing party MPs who give an EoV seem to be more prone to

\footnotetext{
${ }^{7}$ For a visualisation, see Supplementary Figure S1.

${ }^{8}$ See Supplementary Table S4.
} 
defect in a later vote. To give an example, almost every fourth of the $108 \mathrm{CDU} / \mathrm{CDU}$ MPs who issued a 'support' or 'yes-but' EoV in February 2015 voted against their own party later that year. In the next section, we test this sequential relationship between EoVs and voting defection more systematically using a time series regression model.

\subsection{Regression analyses}

[Insert Table 3 here]

Table 3 reveals that among our independent variables, only rank shows a statistically significant effect for all three types of individual-level activity (with the exception of defection in Model 2). Following intuitive logic and confirming our expectation that MPs in a high-ranking position are less likely to express grievances against the official party line (Hypothesis 2), backbenchers are unlikely to get floor time in these highly salient debates, whereas frontbenchers are less inclined to deliver an EoV or cast a deviant vote.

Contrary to our expectation (Hypothesis 1) that district MPs may be more responsive to the electorate, which is very sceptical about financial assistance to Greece, mandate type does not seem to matter for voting behaviour. In fact, district MPs are also less inclined to explain their voting decision ( $c f$. Zittel and Nyhuis, this issue), indicating that EoVs offer a channel of communication for MPs who find the threshold of defection too high or have more to lose, as list MPs are more dependent on their party leadership for re-election.

Confirming Hypothesis 3a, conformist voting behaviour decreases with years of experience, but simultaneously the least experienced MPs make more use of EoVs. In debates that party leaders consider most important, newcomers lack access to the plenary floor, but given the salience and media attention of the votes on the Greek crisis, less experienced MPs are motivated to utilise other channels of communication such as EoVs. In Model 2 we test 
the rebelliousness of experienced MPs with a backbench position (Hypothesis 3b). Indeed, in the case of defection, the independent effects found for rank and experience vanish, while the combined effect is very strong.

Looking at gender effects, our evidence confirms that women MPs are underrepresented in plenary debates on the Greek crisis, which is in line with Bäck et al.'s findings and Hypothesis 4. On the other hand, compared to their male colleagues, female MPs show higher levels of activity with regards to EoVs. Considering the other findings regarding the usage of EoVs, this leads us to argue that when controversiality is rising, as was certainly the case with the Greek crisis, but this is not sufficiently reflected in the plenary debates, EoVs provide an 'outlet', that is, a worthwhile exercise to raise their voice, in particular for backbenchers, the least experienced MPs, list MPs and - in 'hard' policy issues like this one - also female MPs. The fact that EoVs are even used quite extensively to express support for the party position is a meaningful indicator of widespread intra-party contestation.

Lastly, the party control variable reveals that members of the SPD, Left Party and Greens are less likely to cast a deviant vote and deliver an EoV than their CDU colleagues, which shows that increasing disunity was to a large extent driven by the Christian Democrats. As shown by Zittel and Nyhuis (this issue), this finding is contrary to the general tendencies in the Bundestag, as we would expect party unity to be highest in the CDU and CSU and lowest in the Green Party and SPD. We may thus wonder why there is a backbench rebellion on this issue among the Christian Democrats but not, for example, the other large centrist party, the Social Democrats. Considering that there are strong conservative forces within the $\mathrm{CDU} / \mathrm{CSU}$, this finding supports the claim of cleavage theory that conservative parties are most inclined to internal dissent on EU issues.

The analysis presented above is static in the sense that it does not take into account 
previous actions. Although there is a plethora of scholarly work on the positive impact of previous RCVs on current ones (e.g. Hirano, 2008; Degner and Leuffen, 2016), to the best of our knowledge, there are no empirical findings regarding legislative speech and EoVs. To test how previous actions affect legislative behaviour, we repeat the analysis (only for Model $1^{9}$ ) adding the lagged value $(L$.$) of the dependent variables { }^{10}$.

\section{[Insert Table 4 here]}

Comparing the results between Table 3 and 4, the first key observation is that rank maintains the same effect and its statistical significance for all three activities. Furthermore, we observe that defecting in one vote increases the odds of casting a deviant vote in the next vote by eleven times. It seems that dissenters, especially from the governing parties, have little incentive to change their voting behaviour once they have crossed the threshold of defection, given that the issue at hand has become more contested while the government's official position on the Greek crisis remained largely unaltered. In the case of EoVs, we see an effect in the opposite direction: MPs are more likely to explain their voting decision if they have not done so in the previous debate. Apparently, an MP who delivered an EoV in the past does not have a strong motivation to explain her decision again if her opinion on the issue has remained unchanged. What is even more intriguing, our results (see Model B) show that an MP who explained her voting decision is two times more likely to defect in a future vote. In

\footnotetext{
${ }^{9}$ The results are more or less the same under Model 2 (available upon request), but since the variable 'Backbencher_Experience $>8$ ' is not statistically significant under Model 2, we present only the results of Model 1.

${ }^{10}$ Some scholars argue against the use of lagged dependent variables in a random effects model, since it usually suppresses the explanatory power of the other independent variables (Achen, 2001), but this is not an issue here, at least for the bulk of cases presented in Table 4. Also adding lagged dependent variables in our study is paramount as we are dealing with the same issue, the Greek crisis, in five episodes that are interrelated. Therefore, how MPs behaved at $t-1$ also affects how they behave at $t$.
} 
other words, EoVs are a first step towards deviant voting and can function as a 'warning' mechanism for party leaderships.

To sum up, our results highlight that a legislator's rank within his party matters and that intra-party contestation on the Greek crisis was largely driven by backbenchers and by the Christian Democrats. Also the years of experience as an MP and even gender are relevant in explaining activity patterns in the Bundestag. On this particular issue, there is no conclusive evidence of a 'mandate divide'.

\section{Conclusion}

When talking about the politicisation, meaning increasing contestation and domestication, of EU politics, we cannot simply assume that national legislatures would be a driving force, as these processes are both enabled and constrained by institutional conditions, which are to a large extent shaped by political parties. This study is premised on the argument that the German Bundestag is anything but an obvious case of EU contestation. Since the onset of the euro crisis at the latest, cracks emerged in the pro-EU cross-partisan consensus, and in line with earlier theoretical propositions dissent started to form within mainstream parties at least as much as between parties. As it is in the interest of the party leadership to maintain a cohesive party label and party discipline is generally strong in the Bundestag, we discuss the theoretical implications of party control and test how it affects individual-level activity and thus party (dis)unity around the Greek crisis, a contentious policy issue that has received more and more public attention over the years.

Given the salience of the issue, party leaders exercise tight control of the Bundestag's plenum, resulting in plenary debates dominated by party leaders themselves and other experienced frontbenchers, who toe the party line. The debates therefore did not adequately 
reflect the increasing contentiousness of the Greek crisis, but the disintegration of the consensus within legislative parties, particularly the Christian Democrats, became evident in voting disunity and the extensive usage of EoVs. To the best of our knowledge, our analysis establishes for the first time a link between EoVs and deviant voting, as we show that MPs who justify their voting decision are more likely to vote against their party in a future vote. This finding emphasises the dynamic and sequential nature of party disunity. Especially in a legislature where party discipline and control are very high, voting dissent - although often the prime focus of the literature - is only the final (and most easily observed) stage.

This article also stresses the value of in-depth case studies for the study of party unity, in that they enhance our understanding of the contextual determinants of party unity. In addition to, for instance, time factors and issue variance, we should closely examine actors within legislative parties. At the beginning of this article we ask whether backbenchers, who tend to be more critical of extending the EU's competences any further, have learned to fight back and make their dissenting voices heard within parliament. Out of all individual-level variables, our results show the most consistent effect regarding MPs' rank. Since the channel of legislative speech is often closed to them, it remains questionable though to what extent they can actually influence the public debate. The next logical step would be to analyse the impact of growing voting dissent and disagreement with the party line expressed in EoVs on the actual content of plenary debates. In other words, we need to ask how the absence of certain actors shapes the publicly visible debates, addressing the question why it matters who speaks for the party. 
Table 1 Bundestag RCVs on euro crisis measures and aid packages

\begin{tabular}{ll}
\hline \multicolumn{1}{c}{ Date } & \multicolumn{1}{c}{ Acts } \\
\hline $17^{\text {th }}$ legislative term & \\
7 May 2010 & First aid package for Greece \\
21 May 2010 & Creation of the EFSF \\
29 September 2011 & Expansion of the EFSF \\
27 February 2012 & Second aid package for Greece \\
29 June 2012 & Creation of the ESM \\
19 July 2012 & Rescue package for Spanish banks \\
18 April 2013 & Aid package for Cyprus \\
& Aid package for Portugal \\
& Aid package for Ireland \\
18 th $^{\text {legislative term }}$ & \\
27 February 2015 & Extension of second aid package for Greece \\
17 July 2015 & Government mandate for negotiations with Greece on third aid package \\
19 August 2015 & Third aid package for Greece \\
\hline
\end{tabular}

Table 2 Percentage of total MPs who participated by type of activity

\begin{tabular}{lccc}
\hline \multicolumn{1}{c}{ RCV } & Speech & Defection & EoV \\
\hline Greece I & 2.3 & 2.3 & 10.5 \\
EFSF & 1.8 & 1.8 & 3.2 \\
EFSF expansion & 2.3 & 2.9 & 12.6 \\
Greece II & 2.1 & 4.7 & 11.8 \\
ESM & 3.2 & 4.4 & 13.4 \\
Spain & 2.9 & 8.1 & 3.9 \\
Cyprus, Portugal, Ireland & 2.1 & 6.6 & 9.2 \\
Greece II extension & 2.1 & 7.1 & 21.7 \\
Greece III negotiations & 2.9 & 11.3 & 19.7 \\
Greece III & 2.7 & 13.6 & 7.0 \\
\hline
\end{tabular}


Table 3 OR estimates of two-level random intercept logistic

\begin{tabular}{|c|c|c|c|c|c|c|}
\hline & \multicolumn{2}{|c|}{$\begin{array}{c}\text { Speech } \\
(95 \% \mathrm{CI})\end{array}$} & \multicolumn{2}{|c|}{$\begin{array}{l}\text { Defection } \\
(95 \% \mathrm{CI})\end{array}$} & \multicolumn{2}{|c|}{$\begin{array}{c}\mathrm{EoV}^{11} \\
(95 \% \mathrm{CI})\end{array}$} \\
\hline & Model 1 & Model 2 & Model 1 & Model 2 & Model 1 & Model 2 \\
\hline $\begin{array}{l}\text { Rank: } \\
\text { Backbencher }\end{array}$ & $\begin{array}{l}.154 * * \\
(.085) \\
\end{array}$ & $\begin{array}{l}.031 * * * \\
(.027) \\
\end{array}$ & $\begin{array}{l}3.064 * * \\
(1.204) \\
\end{array}$ & $\begin{array}{l}1.049 \\
(.529)\end{array}$ & $\begin{array}{l}2.069 * * * \\
(.326)\end{array}$ & $\begin{array}{l}1.918 * * * \\
(.438)\end{array}$ \\
\hline $\begin{array}{l}\text { Mandate: } \\
\text { Direct }\end{array}$ & $\begin{array}{l}5.015^{* *} \\
(3.093) \\
\end{array}$ & $\begin{array}{l}5.297^{*} \\
(3.630) \\
\end{array}$ & $\begin{array}{l}1.319 \\
(.454) \\
\end{array}$ & $\begin{array}{l}1.302 \\
(.446)\end{array}$ & $\begin{array}{l}.728^{*} \\
(.115) \\
\end{array}$ & $\begin{array}{l}.727^{*} \\
(.114) \\
\end{array}$ \\
\hline Experience: $\leq 8$ & & & & & & \\
\hline $9-16$ & $\begin{array}{l}2.163 \\
(1.253)\end{array}$ & $\begin{array}{l}.713 \\
(.486)\end{array}$ & $\begin{array}{l}2.012^{*} \\
(.667)\end{array}$ & $\begin{array}{l}.485 \\
(.291)\end{array}$ & $\begin{array}{l}.655^{* *} \\
(.096)\end{array}$ & $\begin{array}{l}.589 \\
(.163)\end{array}$ \\
\hline $17-24$ & $\begin{array}{l}3.631 \\
(2.645)\end{array}$ & $\begin{array}{l}1.213 \\
(.967)\end{array}$ & $\begin{array}{l}1.719 \\
(.782)\end{array}$ & $\begin{array}{l}.444 \\
(.300)\end{array}$ & $\begin{array}{l}.864 \\
(.153)\end{array}$ & $\begin{array}{l}.782 \\
(.230)\end{array}$ \\
\hline $25+$ & $\begin{array}{l}4.664^{*} \\
(3.110)\end{array}$ & $\begin{array}{l}1.534 \\
(1.395)\end{array}$ & $\begin{array}{l}3.963 * \\
(2.441)\end{array}$ & $\begin{array}{l}1.072 \\
(.821)\end{array}$ & $\begin{array}{l}.636 \\
(.211)\end{array}$ & $\begin{array}{l}.577 \\
(.220)\end{array}$ \\
\hline $\begin{array}{l}\text { Gender: } \\
\text { Female }\end{array}$ & $\begin{array}{l}.231 * \\
(.131) \\
\end{array}$ & $\begin{array}{l}.225^{*} \\
(.135)\end{array}$ & $\begin{array}{l}.963 \\
(.307)\end{array}$ & $\begin{array}{l}.977 \\
(.317) \\
\end{array}$ & $\begin{array}{l}1.452^{* *} \\
(.171) \\
\end{array}$ & $\begin{array}{l}1.457^{* *} \\
(.172) \\
\end{array}$ \\
\hline $\begin{array}{l}\text { Government } \\
\text { coalition: Yes }\end{array}$ & $\begin{array}{l}1.849 \\
(1.522)\end{array}$ & $\begin{array}{l}2.694 \\
(2.475)\end{array}$ & $\begin{array}{l}.247^{*} \\
(.150) \\
\end{array}$ & $\begin{array}{l}.252^{*} \\
(.157)\end{array}$ & $\begin{array}{l}.555^{*} \\
(.133) \\
\end{array}$ & $\begin{array}{l}.557^{*} \\
(.134) \\
\end{array}$ \\
\hline Party: CDU & & & & & & \\
\hline CSU & $\begin{array}{l}.382 \\
(.331)\end{array}$ & $\begin{array}{l}.411 \\
(.359)\end{array}$ & $\begin{array}{l}1.899 \\
(.900)\end{array}$ & $\begin{array}{l}2.004 \\
(.964)\end{array}$ & $\begin{array}{l}1.111 \\
(.262)\end{array}$ & $\begin{array}{l}1.115 \\
(.263)\end{array}$ \\
\hline SPD & $\begin{array}{l}1.857 \\
(1.471)\end{array}$ & $\begin{array}{l}2.108 \\
(1.675)\end{array}$ & $\begin{array}{l}.100 * * * \\
(.064)\end{array}$ & $\begin{array}{l}.094 * * * \\
(.062)\end{array}$ & $\begin{array}{l}.599 * * \\
(.111)\end{array}$ & $\begin{array}{l}.598 * * \\
(.111)\end{array}$ \\
\hline FDP & $\begin{array}{l}11.633^{* *} \\
(9.553)\end{array}$ & $\begin{array}{l}13.864 * * \\
(12.602)\end{array}$ & $\begin{array}{l}1.251 \\
(.894)\end{array}$ & $\begin{array}{l}1.194 \\
(.823)\end{array}$ & $\begin{array}{l}1.453 \\
(.450)\end{array}$ & $\begin{array}{l}1.451 \\
(.448)\end{array}$ \\
\hline Left Party & $\begin{array}{l}5.446 \\
(6.906)\end{array}$ & $\begin{array}{l}7.561 \\
(10.693)\end{array}$ & $\begin{array}{l}.194^{*} \\
(.147)\end{array}$ & $\begin{array}{l}.179 * \\
(.140)\end{array}$ & $\begin{array}{l}.430^{*} \\
(.141)\end{array}$ & $\begin{array}{l}.428^{* *} \\
(.140)\end{array}$ \\
\hline Greens & $\begin{array}{l}13.610 \\
(18.583)\end{array}$ & $\begin{array}{l}22.682^{*} \\
(34.909)\end{array}$ & $\begin{array}{l}.027 * * * \\
(.025)\end{array}$ & $\begin{array}{l}.026 * * * \\
(.024)\end{array}$ & $\begin{array}{l}.518^{*} \\
(.171)\end{array}$ & $\begin{array}{l}.519^{*} \\
(.171)\end{array}$ \\
\hline $\begin{array}{l}\text { Backbencher } \\
\text { Experience }>8\end{array}$ & & $\begin{array}{l}11.386^{*} \\
(12.642) \\
\end{array}$ & & $\begin{array}{l}5.555^{*} \\
(3.777) \\
\end{array}$ & & $\begin{array}{l}1.141 \\
(.338) \\
\end{array}$ \\
\hline $\begin{array}{l}\text { Condition } \\
\text { number }\end{array}$ & 18.667 & 20.311 & 18.954 & 19.180 & 15.244 & 15.496 \\
\hline $\begin{array}{l}\text { MP-level } \\
\text { variance }\end{array}$ & $\begin{array}{l}3.365 \\
(1.114) \\
\end{array}$ & $\begin{array}{l}3.781 \\
(1.298) \\
\end{array}$ & $\begin{array}{l}2.123 \\
(.671) \\
\end{array}$ & $\begin{array}{l}2.230 \\
(.704) \\
\end{array}$ & $\begin{array}{l}6.642 \mathrm{e}-24 \\
(4.110 \mathrm{e}-19)\end{array}$ & $\begin{array}{l}2.767 \mathrm{e}-25 \\
(1.013 \mathrm{e}-19)\end{array}$ \\
\hline log likelihood & -180.866 & -177.225 & -414.990 & -411.628 & -756.167 & -756.084 \\
\hline $\mathrm{N}($ level 1) & 1240 & 1240 & 1240 & 1240 & 1240 & 1240 \\
\hline $\mathrm{N}$ (level 2) & 401 & 401 & 401 & 401 & 401 & 401 \\
\hline
\end{tabular}

Notes: Results are displayed in terms of odds ratio (OR); estimates have been computed using Stata programme: gllamm; robust standard errors given in parentheses; $* \mathrm{p}<.05$; ** $\mathrm{p}<.01 ; * * * \mathrm{p}<.001$.

\footnotetext{
${ }^{11}$ Since there are three types of EoV (support, yes-but and defect) that can be ordered, we also run two ordinal logit models, one for Model 1 and one for Model 2. Results were statistically significant only for two variables, government coalition and party, which is not surprising given the small $\mathrm{N}(=401)$.
} 
Table 4 OR estimates of two-level random intercept logistic with lagged $(L$.$) variables$

\begin{tabular}{|c|c|c|c|c|}
\hline & $\begin{array}{l}\text { Speech } \\
(95 \% \mathrm{CI})\end{array}$ & $\begin{array}{c}\mathrm{EoV} \\
(95 \% \mathrm{CI})\end{array}$ & $\begin{array}{l}\text { Defection } \\
(95 \% \text { CI }) \\
\text { Model A } \\
\end{array}$ & $\begin{array}{c}\text { Defection } \\
(95 \% \text { CI }) \\
\text { Model B } \\
\end{array}$ \\
\hline L.Speech & $\begin{array}{l}3.009 \\
(2.793) \\
\end{array}$ & - & - & - \\
\hline L.Defection & - & - & $\begin{array}{l}11.359 * * * \\
(3.472)\end{array}$ & - \\
\hline$L . \mathrm{EoV}$ & - & $\begin{array}{l}.617 * * \\
(.114)\end{array}$ & - & $\begin{array}{l}2.400 * * \\
(.768)\end{array}$ \\
\hline $\begin{array}{l}\text { Rank: } \\
\text { Backbencher }\end{array}$ & $\begin{array}{l}.185^{*} \\
(.127)\end{array}$ & $\begin{array}{l}1.988^{* *} \\
(.405)\end{array}$ & $\begin{array}{l}2.523 * * \\
(.721)\end{array}$ & $\begin{array}{l}3.505^{* *} \\
(1.492)\end{array}$ \\
\hline $\begin{array}{l}\text { Mandate: } \\
\text { Direct }\end{array}$ & $\begin{array}{l}3.642 \\
(2.901)\end{array}$ & $\begin{array}{l}.949 \\
(.222)\end{array}$ & $\begin{array}{l}.939 \\
(.277) \\
\end{array}$ & $\begin{array}{l}1.173 \\
(.490)\end{array}$ \\
\hline Experience: $\leq 8$ & & & & \\
\hline $9-16$ & $\begin{array}{l}3.530 \\
(2.759)\end{array}$ & $\begin{array}{l}.594 * * \\
(.111)\end{array}$ & $\begin{array}{l}1.213 \\
(.309)\end{array}$ & $\begin{array}{l}1.653 \\
(.656)\end{array}$ \\
\hline $17-24$ & $\begin{array}{l}6.504^{*} \\
(6.173)\end{array}$ & $\begin{array}{l}.780 \\
(.169)\end{array}$ & $\begin{array}{l}1.210 \\
(.385)\end{array}$ & $\begin{array}{l}1.285 \\
(.646)\end{array}$ \\
\hline $25+$ & $\begin{array}{l}5.552 \\
(5.193)\end{array}$ & $\begin{array}{l}.537 \\
(.200)\end{array}$ & $\begin{array}{l}1.251 \\
(.561)\end{array}$ & $\begin{array}{l}2.679 \\
(1.946)\end{array}$ \\
\hline $\begin{array}{l}\text { Gender: } \\
\text { Female }\end{array}$ & $\begin{array}{l}.212^{*} \\
(.151)\end{array}$ & $\begin{array}{l}1.499^{*} \\
(.255)\end{array}$ & $\begin{array}{l}.713 \\
(.189)\end{array}$ & $\begin{array}{l}.654 \\
(.261)\end{array}$ \\
\hline $\begin{array}{l}\text { Government } \\
\text { coalition: Yes }\end{array}$ & $\begin{array}{l}2.019 \\
(2.247)\end{array}$ & $\begin{array}{l}.242 * * * \\
(.083)\end{array}$ & $\begin{array}{l}.205^{*} \\
(.154)\end{array}$ & $\begin{array}{l}.147^{*} \\
(.114)\end{array}$ \\
\hline Party: CDU & & & & \\
\hline CSU & $\begin{array}{l}.405 \\
(.438)\end{array}$ & $\begin{array}{l}1.091 \\
(.340)\end{array}$ & $\begin{array}{l}1.531 \\
(.490)\end{array}$ & $\begin{array}{l}2.458 \\
(1.373)\end{array}$ \\
\hline SPD & $\begin{array}{l}2.338 \\
(1.999)\end{array}$ & $\begin{array}{l}.984 \\
(.253)\end{array}$ & $\begin{array}{l}.109 * * \\
(.070)\end{array}$ & $\begin{array}{l}.078 * * \\
(.061)\end{array}$ \\
\hline FDP & $\begin{array}{l}16.393^{*} \\
(22.359)\end{array}$ & $\begin{array}{l}.477 \\
(.320)\end{array}$ & $\begin{array}{l}1.538 \\
(.881)\end{array}$ & $\begin{array}{l}1.329 \\
(1.159)\end{array}$ \\
\hline Left Party & $\begin{array}{l}6.046 \\
(10.560)\end{array}$ & $\begin{array}{l}.386^{*} \\
(.180)\end{array}$ & $\begin{array}{l}.098 * * \\
(.086)\end{array}$ & $\begin{array}{l}.099 * \\
(.095)\end{array}$ \\
\hline Greens & $\begin{array}{l}17.422 \\
(32.223)\end{array}$ & $\begin{array}{l}.220 * * \\
(.107)\end{array}$ & $\begin{array}{l}.005^{* * *} \\
(.006)\end{array}$ & $\begin{array}{l}.002 * * * \\
(.002)\end{array}$ \\
\hline $\begin{array}{l}\text { Condition } \\
\text { number }\end{array}$ & 21.222 & 16.146 & 24.213 & 20.011 \\
\hline $\begin{array}{l}\text { MP-level } \\
\text { variance }\end{array}$ & $\begin{array}{l}4.087 \\
(2.901)\end{array}$ & $\begin{array}{l}6.084 \mathrm{e}-24 \\
(4.618 \mathrm{e}-18)\end{array}$ & $\begin{array}{l}3.897 \mathrm{e}-21 \\
(4.640 \mathrm{e}-17)\end{array}$ & $\begin{array}{l}2.975 \\
(1.277)\end{array}$ \\
\hline log likelihood & -123.768 & -496.867 & -278.890 & -300.059 \\
\hline $\mathrm{N}($ level 1) & 842 & 842 & 842 & 842 \\
\hline $\mathrm{N}$ (level 2) & 393 & 393 & 393 & 393 \\
\hline
\end{tabular}

Notes: Results are displayed in terms of odds ratio (OR); estimates have been computed using Stata programme: gllamm; robust standard errors given in parentheses; $* \mathrm{p}<.05$; ** $\mathrm{p}<.01 ; * * * \mathrm{p}<.001$. 

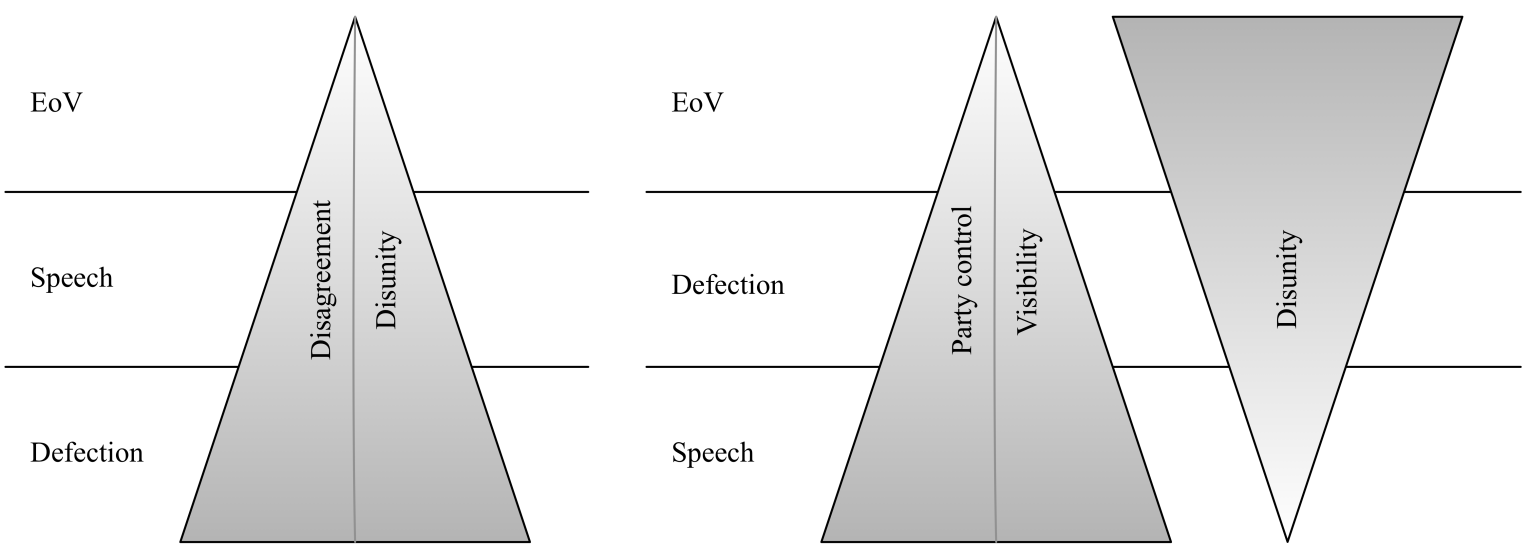

Figure 1 Relationship between latent disagreement and observable disunity following Proksch and Slapin (2015a) (left); expected relationship between party control and intra-party disunity by type of activity (right)

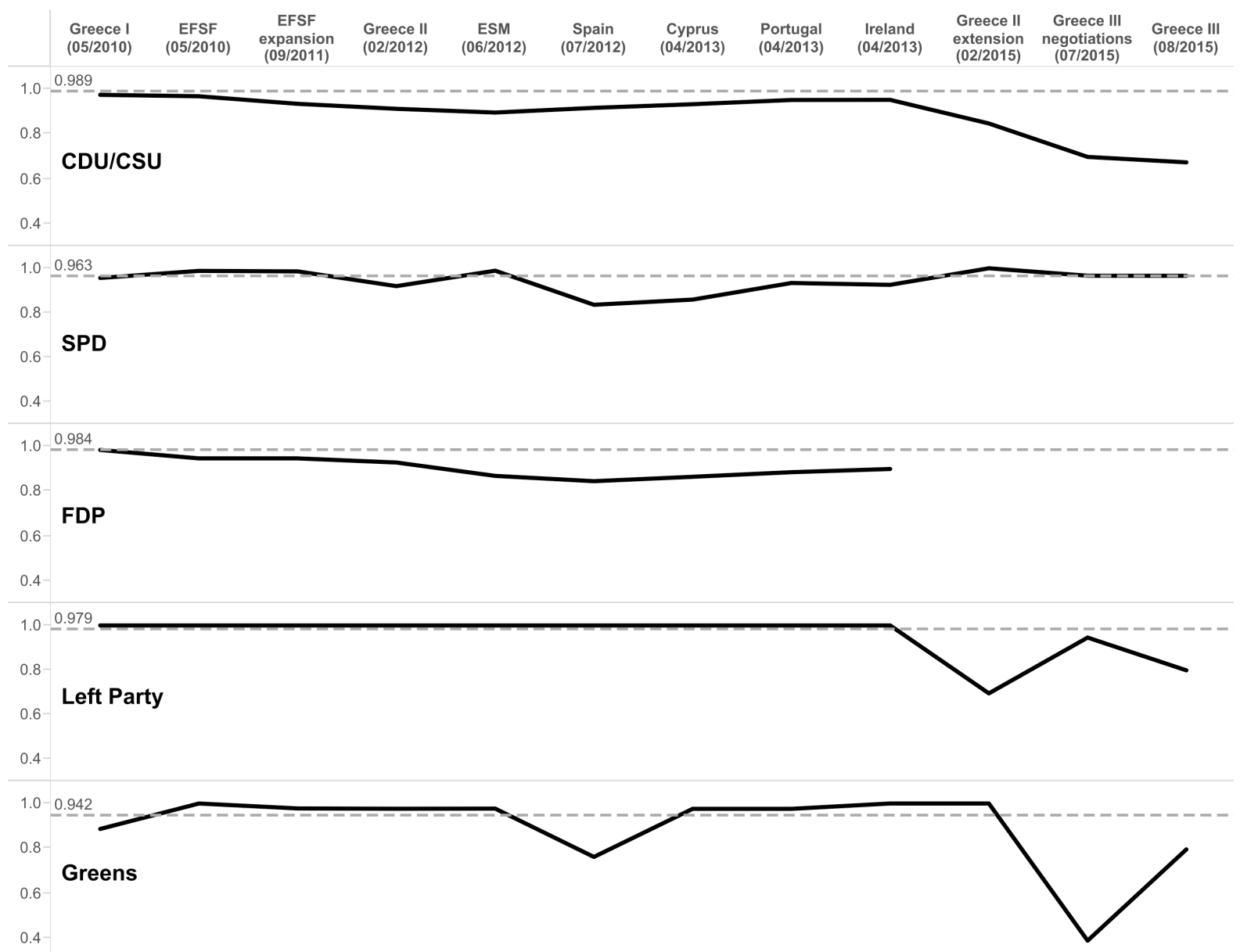

Figure 2 Agreement Index (Hix et al., 2003) for RCVs on euro crisis measures compared to average levels of the $17^{\text {th }}$ term (Bergmann et al., 2016) by party group 


\section{References}

Achen, C. H. (2001) 'Why Lagged Dependent Variables Can Suppress the Explanatory Power of Other Independent Variables', Prepared for the Annual Meeting of the Political Methodology Section of the American Political Science Association, UCLA, July 20-22, 2000.

André, A., Freire, A. and Papp, Z. (2014) 'Electoral Rules and Legislators' Personal Voteseeking'. In Deschouwer, K. and Depauw, S. (eds.) Representing the People: A Survey among Members of Statewide and Sub-state Parliaments, Oxford, Oxford University Press, pp. 87-109.

Auel, K. and Raunio, T. (2014) 'Debating the State of the Union? Comparing Parliamentary Debates on EU Issues in Finland, France, Germany and the United Kingdom', Journal of Legislative Studies, 20, 13-28.

Bäck, H., Debus, M. and Müller, J. (2014) 'Who Takes the Parliamentary Floor? The Role of Gender in Speech-making in the Swedish Riksdag', Political Research Quarterly, 67, 504 518.

Bailer, S. (2017) 'To Use the Whip or Not: Whether and When Party Group Leaders Use Disciplinary Measures to Achieve Voting Unity', International Political Science Review, Advance Access published on 3 January 2017, DOI: 10.1177/0192512116676907.

Becher, M. and Sieberer, U. (2008) 'Discipline, Electoral Rules and Defection in the Bundestag, 1983-94', German Politics, 17, 293-304.

Bergmann, H., Bailer, S., Ohmura, T., Saalfeld, T. and Sieberer, U. (2016) 'Namentliche Abstimmungen im Bundestag 1949 bis 2013: Befunde aus einem neuen Datensatz', Zeitschrift für Parlamentsfragen, 47, 26-50. 
Best, H., and Vogel, L. (2014) 'The Sociology of Legislators and Legislatures'. In Hefftler, C., Neuhold, C., Rozenberg, O. and Smith, J. (eds.) The Palgrave Handbook of National Parliaments and the European Union, Basingstoke, Palgrave Macmillan, pp. 57-81.

Cowley, P. and Childs, Sarah (2003) 'Too Spineless to Rebel? New Labour's Women MPs', British Journal of Political Science, 33, 345-365.

De Wilde, P. (2011) 'No Polity for Old Politics? A Framework for Analyzing Politicization of European Integration', Journal of European Integration, 33, 559-575.

Degner, H. and Leuffen, D. (2016) 'Keynes, Friedman, or Monnet? Explaining Parliamentary Voting Behaviour on Fiscal Aid for Euro Area Member States', West European Politics, 39, $1139-1159$.

Edwards, E. E. (2009) 'Products of Their Past? Cleavages and Intra-Party Dissent over European Integration', Political Science Series, No. 118, Vienna, Institute for Advanced Studies.

Gschwend, T. and Zittel, T. (2015) 'Do Constituency Candidates Matter in German Federal Elections? The Personal Vote as an Interactive Process', Electoral Studies, 39, 338-349.

Hazan, R. Y. (2014) 'Candidate Selection: Implications and Challenges for Legislative Behaviour'. In Martin, S., Saalfeld, T. and Strøm, K. W. (eds.) The Oxford Handbook of Legislative Studies, Oxford, Oxford University Press, pp. 213-230.

Hirano, S. (2008) 'Third Parties, Elections, and Roll-Call Votes: The Populist Party and the Late Nineteenth-Century U.S. Congress', Legislative Studies Quarterly, 33, 131-160.

Hix, S., Kreppel, A. and Noury, A. (2003) 'The Party System in the European Parliament: Collusive or Competitive?', Journal of Common Market Studies, 41, 309-331. 
Hooghe, L. and Marks, G. (2017) ‘Cleavage Theory Meets Europe’s Crises: Lipset, Rokkan, and the Transnational Cleavage', Journal of European Public Policy, Advance Access published on 28 April 2017, DOI: 10.1080/13501763.2017.1310279.

Kam, C. (2014) 'Party Discipline'. In Martin, S., Saalfeld, T. and Strøm, K. W. (eds.) The Oxford Handbook of Legislative Studies, Oxford, Oxford University Press, pp. 399-417.

Kröger, S. and Bellamy, R. (2016) 'Beyond a Constraining Dissensus: The Role of National Parliaments in Domesticating and Normalising the Politicization of European Integration', Comparative European Politics, 14, 131-153.

Manow, P. (2013) 'Mixed Rules, Different Roles? An Analysis of the Typical Pathways into the Bundestag and of MPs' Parliamentary Behaviour', Journal of Legislative Studies, 19, $287-308$.

Marks, G. and Wilson, C. J. (2000) 'The Past in the Present: A Cleavage Theory of Party Response to European Integration', British Journal of Political Science, 30, 433-459.

Mattila, M. and Raunio, T. (2012) 'Drifting Further Apart: National Parties and their Electorates on the EU Dimension', West European Politics, 35, 589-606.

Miklin, E. (2014) 'EU Politicisation and National Parliaments: Visibility of Choices and Better Aligned Ministers?', Journal of Legislative Studies, 20, 78-92.

Ohmura, T. (2014) 'When Your Name Is on the List, It Is Time to Party: The Candidacy Divide in a Mixed-Member Proportional System', Representation, 50, 69-82.

Proksch, S.-O. and Slapin, J. B. (2015a) 'A Theory of Parliamentary Debate'. In The Politics of Parliamentary Debate: Parties, Rebels and Representation, Cambridge, Cambridge University Press, pp. 17-42. 
Proksch, S.-O. and Slapin, J. B. (2015b) 'Debate Participation: Germany and the United Kingdom'. In The Politics of Parliamentary Debate: Parties, Rebels and Representation, Cambridge, Cambridge University Press, pp. 100-123.

Rabe-Hesketh, S. and Skrondal, A. (2012) Multilevel and Longitudinal Modeling Using Stata. College Station, Stata Press.

Rauh, C. (2015) 'Communicating Supranational Governance? The Salience of EU Affairs in the German Bundestag, 1991-2013', European Union Politics, 16, 116-138.

Raunio, T. and Hix, S. (2000) 'Backbenchers Learn to Fight Back: European Integration and Parliamentary Government', West European Politics, 23, 142-168.

Sieberer, U. (2010) 'Behavioural Consequences of Mixed Electoral Systems: Deviating Voting Behaviour of District and List MPs in the German Bundestag', Electoral Studies, 29, 484-496.

Sieberer, U. (2015) 'Using MP Statements to Explain Voting Behaviour in the German Bundestag: An Individual Level Test of the Competing Principals Theory', Party Politics, 21, 284-294.

Van der Eijk, C. and Franklin, M. N. (2004) 'Potential for Contestation on European Matters at National Elections in Europe'. In Marks, G. and Steenbergen, M. R. (eds.) European Integration and Political Conflict, Cambridge, Cambridge University Press, pp. 32-50.

Wendler, F. (2016) Debating Europe in National Parliaments: Public Justification and Political Polarization. London, Palgrave Macmillan.

Zittel, T. and Nyhuis, D. (this issue) 'Two Faces of Party Unity: Roll Call Behaviour and Vote Explanations in the German Bundestag', Parliamentary Affairs. 


\section{Supplementary material}

\section{GLLAMM with adaptive quadrature}

GLLAMMs are 'a class of multilevel latent variable models for (multivariate) responses of mixed type' (Rabe-Hesketh et al., 2004, p. 7) including, among others, dichotomous categorical responses as it is the case here. As the GLLAMM is calculated using adaptive quadrature, its accuracy also depends on the number of integration points. Initially we run the model with quadrature points set at default $(Q$-default $=8)$. We store the vector of parameter estimates and then pass them as starting values to the new model increasing the number of integration points to $Q=12$. We find that differences between the estimates of the two specifications are larger than $0.01 \%$, which is usually the acceptable threshold. Increasing each time the number of integration points we notice that estimates are not affected by the choice of quadrature when $Q=37$. Although this number is four times larger than $Q$-default still all models converge very fast (it only takes four iterations for convergence). Following we keep the same number of integration points employing this time a model specification (xtlogit, re) that uses Gauss-Hermite quadrature (Liu and Pierce, 1994; Lessafre and Spiessens, 2001). Using the same rule of thumb, that is 'if coefficients do not change by more than a relative difference of $10^{-4}(0.01 \%)$, the choice of quadrature points does not significantly affect the outcome' (http://www.stata.com/manuals13/xtquadchk.pdf, accessed 29 March 2017), we find that our model converges extremely well for the same number of quadrature points, that is $Q=37$. The reason that there is no difference found in the number of quadrature points between Gauss-Hermite quadrature and adaptive quadrature is probably due to the small cluster size. Results from the quadrature check between $Q=37$ and $Q_{I}=2 \times \mathrm{Q} / 3$ and $Q_{2}=4 \times \mathrm{Q} / 3$ are given in Table $\mathrm{S} 1$ (Here we only show the results when the response 
variable is speech). From Table A we see that the largest relative difference equals .00001 , a number still smaller than the acceptable threshold.

Supplementary Table S1 Quadrature comparison: Relative differences

\begin{tabular}{llll}
\hline & $\begin{array}{l}\text { Fitted quadrature } \\
37 \text { points }\end{array}$ & $\begin{array}{l}\text { Comparison } \\
\text { quadrature 25 points } \\
\text {------------ } \\
\text { Relative difference }\end{array}$ & $\begin{array}{l}\text { Comparison } \\
\text { quadrature 49 points } \\
\text {------------- } \\
\text { Relative difference }\end{array}$ \\
\hline log likelihood & -180.86555 & $9.345 \mathrm{e}-09$ & $-1.448 \mathrm{e}-10$ \\
Rank & 1.8730188 & $-1.694 \mathrm{e}-07$ & $1.428 \mathrm{e}-09$ \\
Mandate & 1.6125319 & $4.606 \mathrm{e}-08$ & $-4.074 \mathrm{e}-08$ \\
Experience: $9-16$ & .77168358 & $1.054 \mathrm{e}-06$ & $-1.692 \mathrm{e}-07$ \\
Experience: $17-24$ & 1.2896252 & $6.070 \mathrm{e}-07$ & $-9.514 \mathrm{e}-08$ \\
Experience $25+$ & 1.5397672 & $5.337 \mathrm{e}-07$ & $-6.643 \mathrm{e}-08$ \\
Gender & -1.465081 & $5.096 \mathrm{e}-08$ & $-4.245 \mathrm{e}-08$ \\
Government coalition & .61457259 & $-1.552 \mathrm{e}-07$ & $2.385 \mathrm{e}-08$ \\
Party: CDU/CSU & -.96254669 & $3.786 \mathrm{e}-07$ & $-3.401 \mathrm{e}-08$ \\
Party: SPD & .61890103 & $3.956 \mathrm{e}-07$ & $-8.980 \mathrm{e}-08$ \\
Party: FDP & 2.4538516 & $3.671 \mathrm{e}-07$ & $-9.615 \mathrm{e}-08$ \\
Party: Left & 1.6949131 & $3.872 \mathrm{e}-07$ & $-1.073 \mathrm{e}-07$ \\
Party: Greens & 2.610784 & $2.521 \mathrm{e}-07$ & $-5.659 \mathrm{e}-08$ \\
Constant & -7.5883448 & $1.338 \mathrm{e}-07$ & $-4.162 \mathrm{e}-08$ \\
\hline
\end{tabular}

Lesaffre, E. and Spiessens, B. (2001) 'On the Effect of the Number of Quadrature Points in a Logistic Random-Effects Model: An Example', Applied Statistics, 50, 325-335.

Liu, Q. and Pierce, D. A. (1994) 'A Note on Gauss-Hermite Quadrature', Biometrika, 81, $624-629$.

Rabe-Hesketh, S., Skrondal, A. and Pickles, A. (2004) 'GLLAMM Manual', UC Berkeley Division of Biostatisics Working Paper Series, Paper 160, University of California, Berkeley. 
Supplementary Table S2 Count and percentage of district and list MPs by party group

\begin{tabular}{|c|c|c|c|c|c|c|c|c|c|c|c|c|c|c|c|c|c|c|c|c|c|c|c|c|}
\hline \multirow{2}{*}{$\begin{array}{l}\text { Legislative } \\
\text { term }\end{array}$} & \multicolumn{4}{|c|}{$\mathrm{CDU} / \mathrm{CSU}$} & \multicolumn{4}{|c|}{ SPD } & \multicolumn{4}{|c|}{ FDP } & \multicolumn{4}{|c|}{ Left } & \multicolumn{4}{|c|}{ Greens } & \multicolumn{4}{|c|}{ Total } \\
\hline & \multicolumn{2}{|c|}{ District } & \multicolumn{2}{|c|}{ List } & \multicolumn{2}{|c|}{ District } & \multicolumn{2}{|c|}{ List } & \multicolumn{2}{|c|}{ District } & \multicolumn{2}{|c|}{ List } & \multicolumn{2}{|c|}{ District } & \multicolumn{2}{|c|}{ List } & \multicolumn{2}{|c|}{ District } & \multicolumn{2}{|c|}{ List } & \multicolumn{2}{|c|}{ District } & \multicolumn{2}{|c|}{ List } \\
\hline $17^{\text {th }}$ term & 218 & 91.2 & 21 & 8.8 & 64 & 43.8 & 82 & 56.2 & 0 & 0.0 & 93 & 100.0 & 16 & 21.1 & 60 & 78.9 & 1 & 1.5 & 67 & 98.5 & 299 & 48.1 & 323 & 51.9 \\
\hline $18^{\text {th }}$ term & 236 & 75.9 & 75 & 24.1 & 58 & 30.1 & 135 & 69.9 & - & - & - & - & 4 & 6.3 & 60 & 93.8 & 1 & 1.6 & 62 & 98.4 & 299 & 47.4 & 332 & 52.6 \\
\hline
\end{tabular}

Supplementary Table S3 Percentage of MPs who became active, including (Act1) and excluding (Act2) the usage of joint EoVs, by party

\begin{tabular}{|c|c|c|c|c|c|c|c|c|c|c|c|c|c|c|}
\hline \multirow{2}{*}{$\begin{array}{l}\mathrm{RCV} \text { on } \\
\text { Greece }\end{array}$} & \multicolumn{2}{|c|}{ CDU } & \multicolumn{2}{|c|}{$\mathrm{CSU}$} & \multicolumn{2}{|c|}{ SPD } & \multicolumn{2}{|c|}{ FDP } & \multicolumn{2}{|c|}{ Left } & \multicolumn{2}{|c|}{ Greens } & \multicolumn{2}{|c|}{ Total } \\
\hline & $\begin{array}{l}\text { Act1 } \\
(\%)\end{array}$ & $\begin{array}{c}\text { Act2 } \\
(\%)\end{array}$ & $\begin{array}{l}\text { Act1 } \\
(\%)\end{array}$ & $\begin{array}{c}\text { Act2 } \\
(\%)\end{array}$ & $\begin{array}{c}\text { Act1 } \\
(\%)\end{array}$ & $\begin{array}{l}\text { Act2 } \\
(\%)\end{array}$ & $\begin{array}{l}\text { Act1 } \\
(\%)\end{array}$ & $\begin{array}{c}\text { Act2 } \\
(\%)\end{array}$ & $\begin{array}{l}\text { Act1 } \\
(\%)\end{array}$ & $\begin{array}{c}\text { Act2 } \\
(\%)\end{array}$ & $\begin{array}{l}\text { Act1 } \\
(\%)\end{array}$ & $\begin{array}{l}\text { Act2 } \\
(\%)\end{array}$ & $\begin{array}{l}\text { Act1 } \\
(\%)\end{array}$ & $\begin{array}{l}\text { Act2 } \\
(\%)\end{array}$ \\
\hline 07.05 .2010 & 7.7 & 7.7 & 15.6 & 11.1 & 5.5 & 5.5 & 18.3 & 18.3 & 2.6 & 2.6 & 52.9 & 10.3 & 13.7 & 8.7 \\
\hline 27.02.2012 & 7.8 & 7.8 & 15.9 & 15.9 & 33.6 & 8.9 & 9.7 & 9.7 & 28.9 & 25.0 & 11.8 & 2.9 & 17.7 & 10.5 \\
\hline 27.02.2015 & 47.1 & 19.2 & 41.1 & 33.9 & 1.6 & 1.6 & - & - & 29.7 & 29.7 & 7.9 & 4.8 & 26.9 & 14.7 \\
\hline 17.07 .2015 & 27.2 & 26.8 & 37.5 & 35.7 & 21.8 & 11.9 & - & - & 17.2 & 12.5 & 54.0 & 20.6 & 28.1 & 21.0 \\
\hline 19.08.2015 & 23.9 & 23.9 & 30.4 & 30.4 & 6.2 & 6.2 & - & - & 18.8 & 15.6 & 20.6 & 20.6 & 18.2 & 17.9 \\
\hline
\end{tabular}




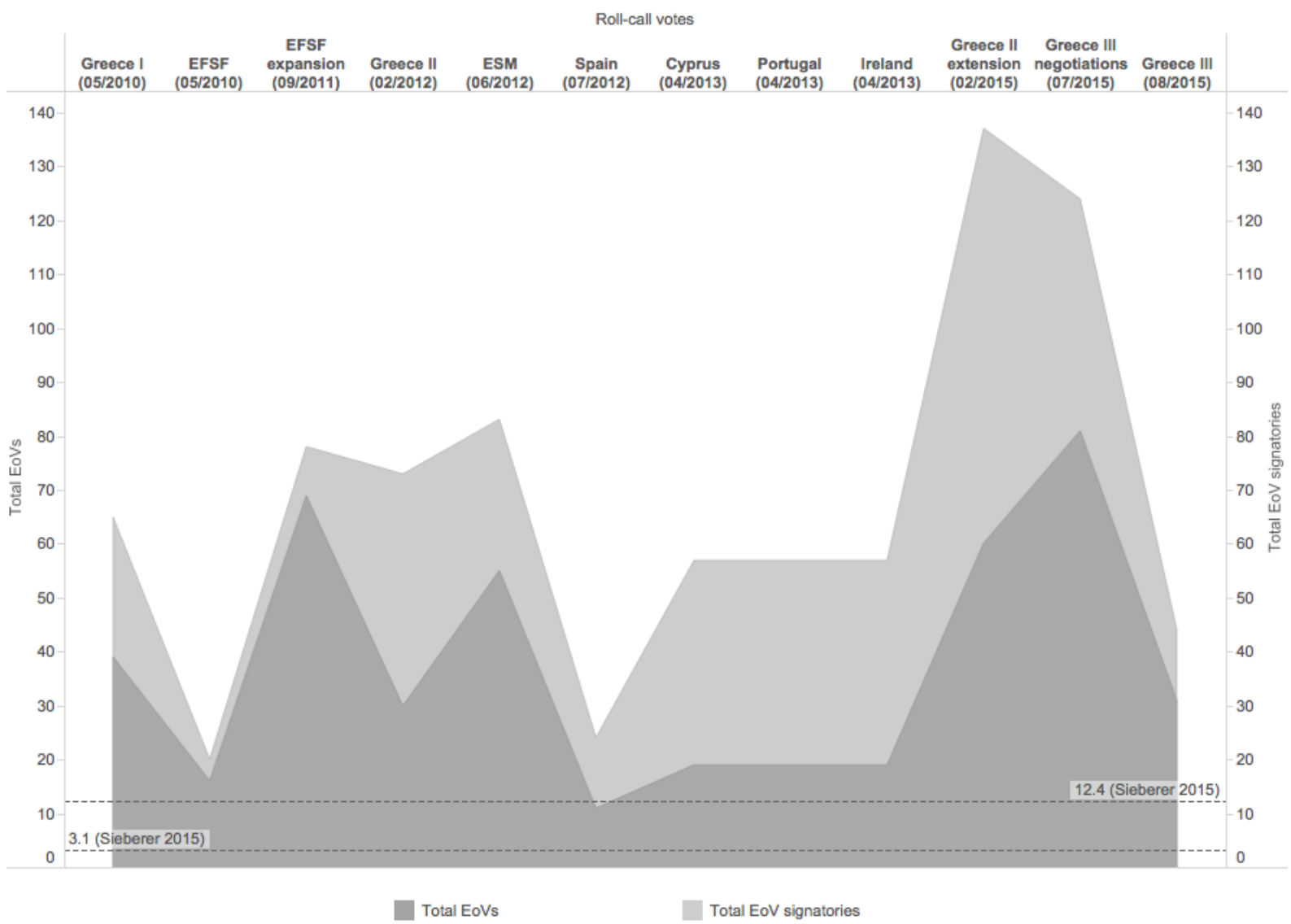

Supplementary Figure S1 Number of EoVs and EoV signatories for RCVs on euro crisis measures and aid packages

Supplementary Table S4 Amount of EoVs by type for RCVs on Greek aid packages

\begin{tabular}{|c|c|c|c|c|c|c|}
\hline Roll-call vote & EoV & & Support & Yes-but & Defect & Total \\
\hline \multirow{3}{*}{$\begin{array}{l}\text { Greece I } \\
\text { adoption }\end{array}$} & \multicolumn{2}{|c|}{ Individual } & 8 & 17 & 10 & 35 \\
\hline & \multirow{2}{*}{ Joint } & EoVs & 0 & 3 & 1 & 4 \\
\hline & & MPs & 0 & 31 & 3 & 34 \\
\hline \multirow{3}{*}{$\begin{array}{l}\text { Greece II } \\
\text { adoption }\end{array}$} & \multicolumn{2}{|c|}{ Individual } & 15 & 2 & 7 & 24 \\
\hline & \multirow{2}{*}{ Joint } & EoVs & 3 & 1 & 2 & 6 \\
\hline & & MPs & 39 & 6 & 4 & 49 \\
\hline \multirow{3}{*}{$\begin{array}{l}\text { Greece II } \\
\text { extension }\end{array}$} & \multicolumn{2}{|c|}{ Individual } & 22 & 15 & 14 & 51 \\
\hline & \multirow{2}{*}{ Joint } & EoVs & 1 & 6 & 2 & 9 \\
\hline & & MPs & 2 & 76 & 8 & 86 \\
\hline \multirow{3}{*}{$\begin{array}{l}\text { Greece III } \\
\text { negotiations }\end{array}$} & \multicolumn{2}{|c|}{ Individual } & 22 & 27 & 26 & 75 \\
\hline & \multirow{2}{*}{ Joint } & EoVs & 3 & 3 & 0 & 6 \\
\hline & & MPs & 28 & 21 & 0 & 49 \\
\hline \multirow{7}{*}{$\begin{array}{l}\text { Greece III } \\
\text { adoption }\end{array}$} & \multicolumn{2}{|c|}{ Individual } & 8 & 7 & 12 & 27 \\
\hline & \multirow{2}{*}{ Joint } & EoVs & 1 & 0 & 2 & 3 \\
\hline & & MPs & 2 & 0 & 13 & 15 \\
\hline & & Total (EoVs) & 83 & 81 & 76 & 240 \\
\hline & & $\%$ & 34.6 & 33.7 & 31.7 & 100.0 \\
\hline & & Total (MPs) & 146 & 202 & 97 & 445 \\
\hline & & $\%$ & 32.8 & 45.4 & 21.8 & 100.0 \\
\hline
\end{tabular}

